\title{
Growth Responses of Heptacodium miconioides to Various Photoperiods and Day/Night Temperatures
}

\author{
Chin Chin Lee', Ted E. Bilderback ${ }^{2}$, and Judith F. Thomas ${ }^{3}$ \\ North Carolina State University, Raleigh, NC 27695-7609
}

\begin{abstract}
Additional index words. long-day plant, Heptacodium jasminoides
Abstract. Photoperiod treatments of 10, 12, 14, and 16 hours and a field control were used to determine the photoperiodic response of Heptacodium miconioides Rehd. The F values for vegetative growth responses under various photoperiods exhibited a highly significant linear effect. Leaf count, area, and weight, shoot length, and stem weight were lower for plants exposed to the 10- or 12-hour photoperiod than those of plants grown under the 14- or 16-hour photoperiod or in the field. Plants under the 10- or 12-hour photoperiod became dormant after 5 weeks of treatment. The growth responses for the 10- and 12-hour photoperiods were similar. There also were no differences in growth responses of plants from the 14- and 16-hour photoperiods or from the field. A favorable photoperiod for growth of Heptacodium must exceed 12 hours; thus, it can be classified as a long-day plant in reference to vegetative growth. Leaf tissues under the 10- and 12-hour photoperiods were significantly thicker than those under the 14- and 16-hour periods or under field conditions due to longer cells of the palisade mesophyll layer. Plants grown in the field and under the 14- or 16-hour photoperiods were the only ones that initiated inflorescences. With days at 30C, leaf and stem dimensions were larger than those at $22 \mathrm{C}$. Nights at $18 \mathrm{C}$ resulted in a larger leaf area, leaf weight, and stem weight than at $26 \mathrm{C}$. There was a significant effect on total leaf thickness due to day $\times$ night temperature interaction.
\end{abstract}

Heptacodium miconioides (syn. H. jasminoides H.K.A. Shaw; cf. Hu, 1988) is a small, deciduous, flowering tree recently rediscovered through the Sino-American Botanical Expedition in 1980 (Keller, 1986). Heptacodium miconioides is a member of the honeysuckle or Caprifoliaceae family and is grown for its open-vase tree form, fast growth, late blooming season, and fragrant white inflorescences. The persistent calyces on the flowers can turn reddish and become ornate in the fall. Since its introduction to North America, it has been propagated and distributed by the Arnold Arboretum, Jamaica Plain, Mass., and by the North Carolina State Univ. (NCSU) Arboretum to nurserymen and growers in the United States.

Preliminary observations suggested that the growth of Heptacodium could be regulated by photoperiod to increase the amount of growth required for making cuttings or to control plant height and flower induction. Downs and Borthwick (1956) found that Weigela florida var. Variegeta is very sensitive to photoperiod and that control by regulation of daylength is practical in its propagation. To enable us to study the effects of day/night temperature and daylength on the growth and development of Hep-

Received for publication 17 May 1990. The research reported in this publication was funded (in part) by the North Carolina Agricultural Research Service. The cost of publishing this paper was defrayed in part by the payment of page charges. Under postal regulations, this paper therefore must be hereby marked advertisement solely to indicate this fact.

'Present address: Dept. of Agronomy and Horticulture, U.P.M. Serdang, Sel, Malaysia.

${ }^{2}$ Associate Professor, Dept. of Horticultural Science.

${ }^{3}$ Associate Professor, Dept. of Botany. tacodium, two experiments were conducted in the NCSU phytotron. The main objectives were to determine the effects of photoperiod and alternating day/night temperatures on the growth and development of $\mathrm{H}$. miconioides.

\section{Materials and Methods}

Photoperiod (Expt. 1). One-year-old Heptacodium plants in 3.8-liter pots were selected for uniform size and pruned to the third node from the base of the plant before exposing them to various photoperiods. Plants were grown in May 1988 in a temperature-controlled greenhouse (Downs and Thomas, 1991) programmed for a day/night regime of $22 / 18 \mathrm{C}$ and with natural daylight. Recorded temperatures varied not more than $\pm 0.5 \mathrm{C}$ during the day and less than $\pm 0.25 \mathrm{C}$ during the night.

All plants were exposed to $9 \mathrm{~h}$ daylight (0800 HR-1700 HR) then moved into adjacent photoperiod rooms programmed for various daylength extensions to provide four photoperiods -10 , 12,14 , and $16 \mathrm{~h}$. Daylength extensions consisted of low-intensity light obtained from incandescent lamps that provided a photosynthetic photon flux (PPF) of $26 \mu \mathrm{mol} \cdot \mathrm{s}^{-1} \cdot \mathrm{m}^{-2}(400-700$ $\mathrm{nm})$ and a photomorphogenic irradiance (PI) of $4 \mathrm{~W} \cdot \mathrm{m}^{-2}(700-$ $850 \mathrm{~nm}$ ). Twelve plants were used in each treatment and a total of 48 plants were included in the study. Data were recorded weekly for average increases in plant height, and observations were recorded for growth and flowering responses. After 12 weeks, plants were sampled for number of leaves, total leaf area, leaf weight, shoot length, stem weight, and root weight. As a control, 10 one-year-old plants in 3.8-liter pots were grown at the NCSU Unit 4 Container Research Plot under natural con-

Table 1. F values for growth responses of Heptacodium miconioides grown under various daylengths. ${ }^{\mathbf{z}}$

\begin{tabular}{|c|c|c|c|c|c|c|}
\hline \multirow[b]{2}{*}{ Factors } & \multicolumn{3}{|c|}{ Leaf } & \multirow[b]{2}{*}{ Stem wt } & \multirow[b]{2}{*}{ Root wt } & \multirow{2}{*}{$\begin{array}{l}\text { Shoot } \\
\text { length }\end{array}$} \\
\hline & Count & Area & $\mathrm{Wt}$ & & & \\
\hline Daylength & $15.72^{* *}$ & $14.09 * *$ & $13.46^{* *}$ & $15.56^{* *}$ & $7.13^{* *}$ & $21.66^{* *}$ \\
\hline Field vs. others & $21.01^{* *}$ & $0.32^{\mathrm{NS}}$ & $1.32^{\mathrm{NS}}$ & $3.00^{\mathrm{NS}}$ & $16.77^{* *}$ & $2.50^{\mathrm{NS}}$ \\
\hline Linear & $38.21 * *$ & $47.47^{* *}$ & $46.05^{* *}$ & $52.80^{* *}$ & $9.26^{* *}$ & $75.58^{* *}$ \\
\hline Quadratic & $0.73^{\mathrm{NS}}$ & $0.01^{\mathrm{NS}}$ & $0.16^{\mathrm{NS}}$ & $0.71^{\mathrm{Ns}}$ & $1.71^{\mathrm{NS}}$ & $0.59^{\mathrm{NS}}$ \\
\hline
\end{tabular}

$\mathrm{NS}, *, * * \mathrm{~F}$ values nonsignificant or significant at $P=0.05$ or 0.01 , respectively. 
Table 2. F values for the effect of daylength on thickness of various leaf tissues of Heptacodium miconioides.

\begin{tabular}{|c|c|c|c|c|c|}
\hline \multirow[b]{2}{*}{ Factor } & \multicolumn{2}{|c|}{ Mesophyll } & \multicolumn{2}{|c|}{ Epidermis } & \multirow{2}{*}{$\begin{array}{c}\text { Entire } \\
\text { leaf }\end{array}$} \\
\hline & Palisade & Spongy & Lower & Upper & \\
\hline Daylength & $54.13 * *$ & $3.12 *$ & $2.24^{\mathrm{NS}}$ & $6.87 * *$ & $29.81 * *$ \\
\hline Field vs. others & $25.94 * *$ & $9.17 * *$ & $3.47^{\mathrm{NS}}$ & $2.68^{\mathrm{NS}}$ & $20.77 * *$ \\
\hline Linear & $154.91 * *$ & $1.73^{\mathrm{NS}}$ & $5.36^{*}$ & $14.76^{* *}$ & $87.35 * *$ \\
\hline Quadratic & $13.82^{* *}$ & $0.24^{\mathrm{NS}}$ & $0.11^{\mathrm{NS}}$ & $0.61^{\mathrm{Ns}}$ & $3.93^{\mathrm{NS}}$ \\
\hline
\end{tabular}
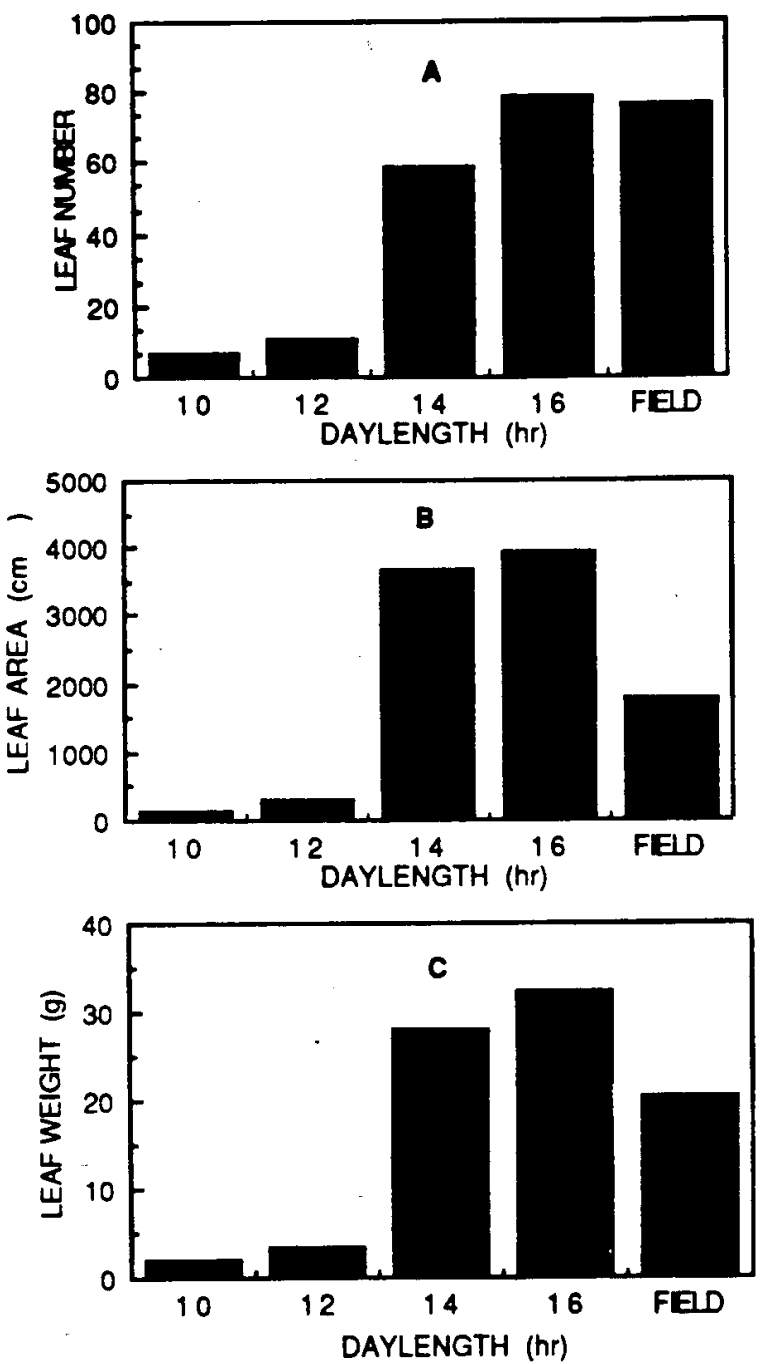

Fig. 1. Effect of photoperiod on (A) number of leaves, (B) leaf area, and (C) leaf weight of Heptacodium miconioides.

ditions (13- to 15-h photoperiod) beginning in May 1988. Weekly readings were recorded for average increases in plant height. After 12 weeks, plants were sampled as described above. We also recorded the flowering status of all treatments.

Leaf disk samples ( $1 \mathrm{~cm}$ in diameter) were collected from the middle of the lamina of fully expanded leaves (avoiding major vascular bundles) of plants grown in the phytotron and from those grown outside. The samples were fixed in formalin acetic acid-alcohol (FAA), dehydrated in an ethyl-butyl alcohol series, and embedded in paraffin.

Leaf cross sections were cut at $10 \mu \mathrm{m}$ and stained with safranin O and fast green (Johansen, 1940). Four leaves were sampled per treatment and two sections were measured for each
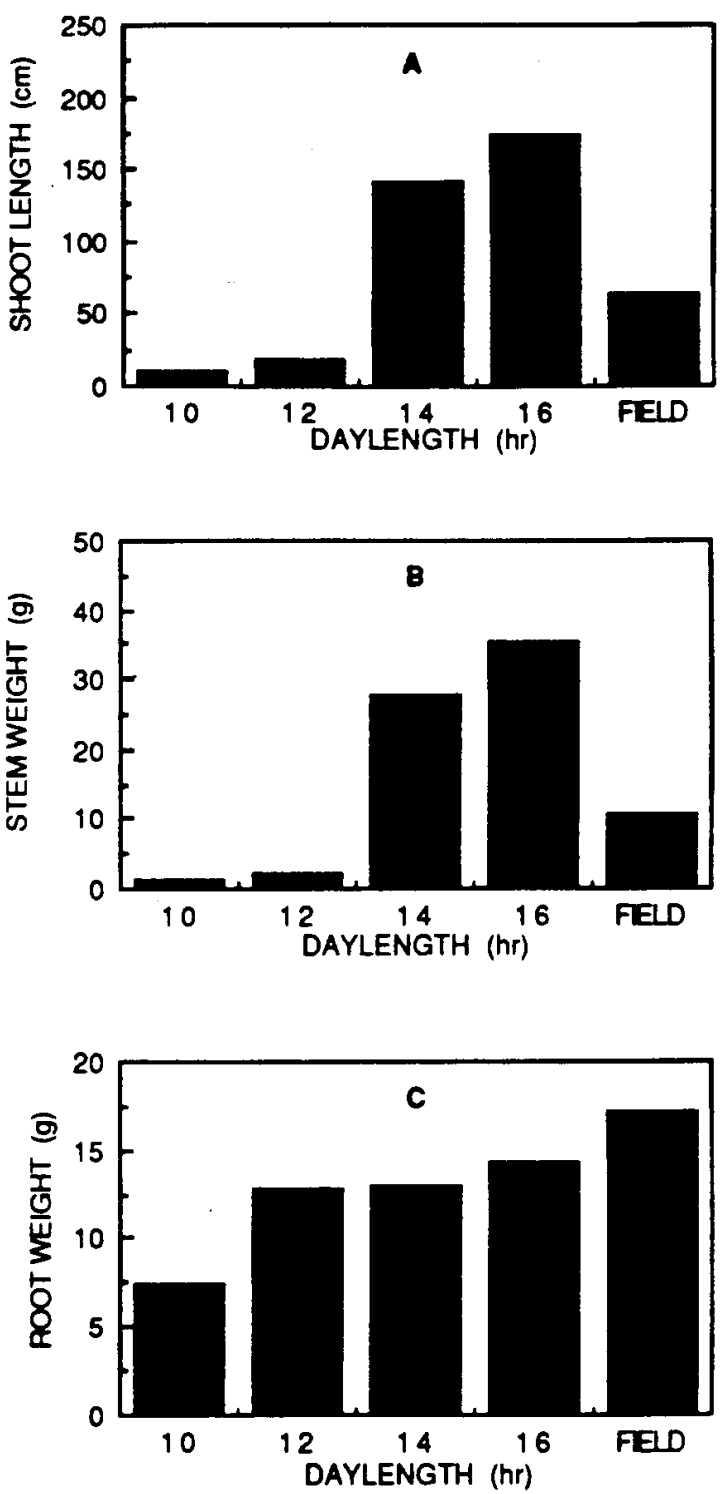

Fig. 2. Effect of photoperiod on (A) shoot length, (B) stem weight, and $(\mathbf{C})$ root weight of Heptacodium miconioides.

leaf, giving a total sample of eight per treatment. Leaf measurements included total thickness and thickness of individual tissues [upper (adaxial) and lower (abaxial) epidermal layers, palisade mesophyll, and spongy mesophyll]. Data were tested using an analysis of variance and orthogonal contrasts of treatments.

Thermoperiod (Expt. 2). Four large, walk-in growth chambers (Downs and Thomas, 1991) were used to provide the required day/night temperature regimes of 30/26, 30/18, 22/26, 
Table 3. Variations in mean thickness $(\mu \mathrm{m})$ of leaf tissues of Heptacodium miconioides in response to daylength. ${ }^{2}$

\begin{tabular}{|c|c|c|c|c|c|}
\hline \multirow{3}{*}{$\begin{array}{l}\text { Daylength } \\
\text { (h) }\end{array}$} & \multicolumn{5}{|c|}{ Thickness $(\mu \mathrm{m})$} \\
\hline & \multicolumn{2}{|c|}{ Mesophyll } & \multicolumn{2}{|c|}{ Epidermis } & \multirow{2}{*}{$\begin{array}{c}\text { Entire } \\
\text { leaf }\end{array}$} \\
\hline & Palisade & $\overline{\text { Spongy }}$ & Lower & Upper & \\
\hline Natural field & 83 & 66.8 & 18.6 & 20.8 & 191 \\
\hline 16 & 84 & 72.7 & 18.2 & 17.9 & 194 \\
\hline 14 & 74 & 78.9 & 17.8 & 17.8 & 192 \\
\hline 12 & 125 & 76.1 & 17.4 & 21.8 & 240 \\
\hline 10 & 147 & 79.4 & 16.7 & 20.5 & 264 \\
\hline \multicolumn{6}{|c|}{ Linear regression $y$} \\
\hline Intercept & 262.9 & 88.0 & 14.2 & 27.2 & 390.1 \\
\hline Slope & -11.9 & -0.9 & 0.3 & -0.6 & -12.9 \\
\hline
\end{tabular}

zMeans of eight leaf sections.

yLinear regression fit for the quantitative treatments $10,12,14$, and $16 \mathrm{~h}$.

Table 4. F values for the effect of day/night temperature on the growth of Heptacodium miconioides. ${ }^{\mathrm{z}}$

\begin{tabular}{|c|c|c|c|c|c|c|c|}
\hline \multirow[b]{2}{*}{ Temp } & \multicolumn{4}{|c|}{ Leaf } & \multirow{2}{*}{$\begin{array}{c}\text { Stem } \\
\text { wt }\end{array}$} & \multirow{2}{*}{$\begin{array}{c}\text { Root } \\
\text { wt }\end{array}$} & \multirow{2}{*}{$\begin{array}{l}\text { Shoot } \\
\text { length }\end{array}$} \\
\hline & Count & Area & $\mathrm{Wt}$ & Thickness & & & \\
\hline Day & $4.29^{*}$ & $9.76^{* *}$ & $6.94^{*}$ & $0.48^{\mathrm{NS}}$ & $7.55^{*}$ & $0.36^{\mathrm{NS}}$ & $0.60^{\mathrm{NS}}$ \\
\hline Night & $0.89^{\mathrm{NS}}$ & $13.79^{* *}$ & $6.72^{*}$ & $15.40^{* *}$ & $12.80^{* *}$ & $0.10^{\mathrm{NS}}$ & $0.81^{\mathrm{NS}}$ \\
\hline Day $\times$ night & $0.00^{\mathrm{NS}}$ & $1.37^{\mathrm{NS}}$ & $0.16^{\mathrm{NS}}$ & $19.73^{* *}$ & $0.24^{\mathrm{NS}}$ & $0.08^{\mathrm{NS}}$ & $0.57^{\mathrm{NS}}$ \\
\hline
\end{tabular}

NS, $* * * \mathrm{~F}$ values nonsignificant or significant at $P=0.05$ or 0.01 , respectively.

Table 5. Growth response means for Heptacodium miconioides grown under various day/night temperatures.

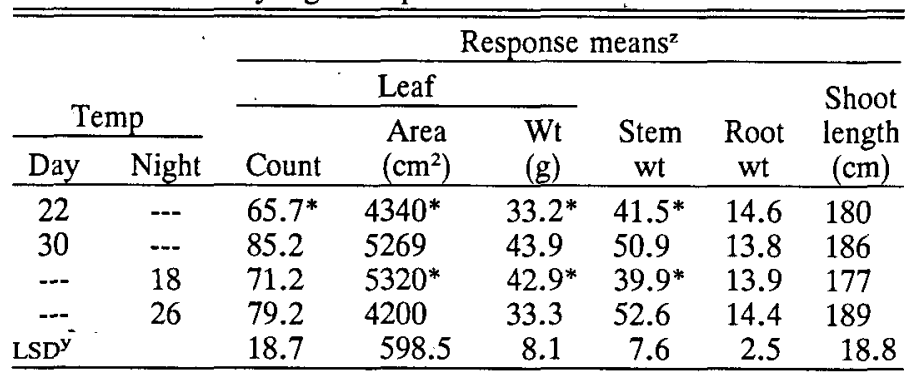

${ }^{2}$ Means of day or night temperatures, each averaged across the other in the absence of interaction.

$\mathrm{y}_{\mathrm{LSD}}$ for comparison within day or within night temperatures at $P=$ 0.05 .

and 22/18C. The photoperiod consisted of $9 \mathrm{~h}$ of high-intensity light from fluorescent and incandescent lamps with a PPF of 670 to $730 \mu \mathrm{mol} \cdot \mathrm{s}^{-1} \cdot \mathrm{m}^{-2}(400-700 \mathrm{~nm})$ and a 3-h interruption of low-intensity light from the incandescent lamps during the middle of the dark period, giving a PPF of $45 \mu \mathrm{mol} \cdot \mathrm{s}^{-1} \cdot \mathrm{m}^{-2}$ and PI of $7 \mathrm{~W} \cdot \mathrm{m}^{-2}$. A total of 48 plants were used with 12 plants for each treatment. Plants were moved between appropriate chambers at 0800 and $1700 \mathrm{HR}$ daily to maintain day/ night temperature regimes. The plants were grown for 12 weeks, and plant heights were measured weekly. After 12 weeks, six plants from each treatment were harvested and the same characteristics were measured as for Expt. 1. Leaf disk samples were collected and similarly treated as for Expt. 1. The data were analyzed for the main effects of day and night temperatures and their interaction effects on the growth of $H$. miconioides.

\section{Results and Discussion}

Photoperiod (Expt. 1). Twelve weeks after the experiment was started, plants grown under the 14- or 16-h photoperiod averaged 139 to $173 \mathrm{~cm}$ in height and touched the ceiling of the photoperiod room. Therefore, the experiment was terminated and all of the plants were sampled.

Daylength clearly influenced the growth of Heptacodium. There were significant linear effects on all vegetative growth responses (Table 1). Leaf counts, area, and weight were significantly lower for plants exposed to the 10- or 12-h photoperiods than for those grown under 14- or 16-h photoperiods or in the field. (Fig. 1 A-C). Leaf growth and expansion are known to be affected by daylength. Long-day (LD) treatments given to other species have shown that leaves of most plants, regardless of photoperiodic class, tended to become larger under longer daylengths (VincePrue, 1975). Shoot length and stem dry weight were also consistently smaller for plants from the 10- and 12-h photoperiods than for those from the 14- or 16-h photoperiods or field con-

Table 6. F values for the effect of day/night temperature on thickness of various leaf tissues of Heptacodium miconioides. ${ }^{\mathrm{z}}$

\begin{tabular}{|c|c|c|c|c|c|}
\hline \multirow[b]{2}{*}{ Factors } & \multicolumn{2}{|c|}{ Mesophyll } & \multicolumn{2}{|c|}{ Epidermis } & \multirow{2}{*}{$\begin{array}{c}\text { Entire } \\
\text { leaf }\end{array}$} \\
\hline & Palisade & Spongy & Lower & Upper & \\
\hline Daylength & $41.23^{* *}$ & $5.45^{* *}$ & $10.19 * *$ & $6.05^{* *}$ & $34.91 * *$ \\
\hline Field vs. others & $120.82^{* *}$ & $13.20^{* *}$ & $3.94^{* *}$ & $10.17^{* *}$ & $104.04^{* *}$ \\
\hline Day temp & $0.90^{\mathrm{NS}}$ & $0.28^{\mathrm{NS}}$ & $0.74^{\mathrm{NS}}$ & $5.08^{*}$ & $0.48^{\mathrm{NS}}$ \\
\hline Night temp & $23.21^{* *}$ & $2.56^{\mathrm{NS}}$ & $6.10^{*}$ & $1.00^{\mathrm{NS}}$ & $15.40^{* *}$ \\
\hline Day $\times$ night temp & $19.98^{* *}$ & $5.76^{*}$ & $0.00^{\mathrm{NS}}$ & $7.92^{* *}$ & $19.73^{* *}$ \\
\hline
\end{tabular}

NS,*,**F values nonsignificant or significant at $P=0.05$ or 0.01 , respectively. 

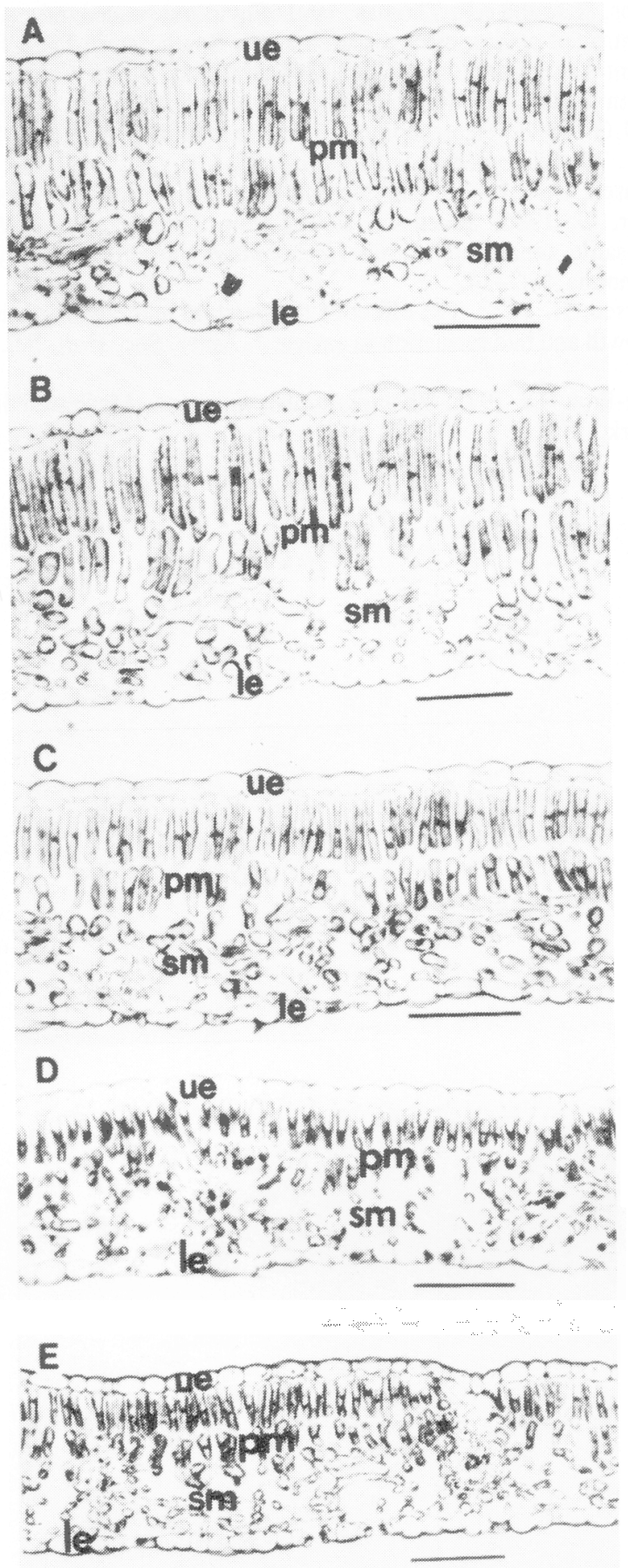

Fig. 3. Cross sections of Heptacodium miconioides leaves showing the upper (adaxial) epidermis (ue), lower (abaxial) epidermis (le), palisade mesophyll (pm), and spongy mesophyll $(\mathrm{sm})$. Bar $=100$ $\mu \mathrm{m}$. Photoperiods: (A) $10 \mathrm{~h}$, (B) $12 \mathrm{~h}$, (C) $14 \mathrm{~h}$, (D) $16 \mathrm{~h}$, and (E) field condition.

ditions (Fig. 2 A and B). Plants under the 10- and 12-h photoperiods became dormant after 5 weeks of treatment. The terminal shoot apex, for example, ceased to grow and there was no further increase in shoot length after the initial 5 weeks. Furthermore, the leaves on these dormant plants became thick and tended to remain on the plant. The onset of dormancy in woody plant species in temperature zones is markedly affected by daylength. The duration of extension growth and the time at which buds became dormant is influenced by daylength. Generally, the rate and duration of elongation growth is increased by LD, while in short days (SD), the rate of growth is decreased and the onset of dormancy is hastened (Vince-Prue, 1975). Downs and Borthwick (1956) found similar growth responses in Acer rubrum, where plants on LD continued to grow, while those on SD ceased growth within 2 to 4 weeks.

Root weight increased linearly with daylength, and field-grown plants had the heaviest roots (Fig. 2C).

Flowering was induced for plants grown under the 14- and 16-h photoperiods and for plants grown under field conditions. All plants grown under the 16-h photoperiod initiated inflorescences 10 weeks after budbreak. Thirty percent of the plants grown under the 14-h photoperiod and $80 \%$ of the plants grown under field conditions initiated inflorescences.

A contrast between treatment means for plants from the 10and 12-h (SD) photoperiods showed that their growth responses were similar (Figs. 1 and 2). Growth responses of plants from the 14- and 16-h (LD) photoperiods also were similar. In comparison, growth of field plants was less than that of 14- or 16$\mathrm{h}$ plants, with a leaf area of only $\approx 50 \%$ and a leaf weight $\approx 65 \%$. Growth of plants exposed to the 10 - and 12 -h photoperiods was significantly less than that of plants from the 14or 16-h photoperiods and from the field. These results indicate that a photoperiod favorable for growth of Heptacodium must exceed $12 \mathrm{~h}$. A similar pattern of response was reported for $W$. florida var. Variegata (Downs and Borthwick, 1956), a woody ornamental also belonging to the Caprifoliaceae family. These data also confirm that $H$. miconioides can be classified as a long-day plant in reference to vegetative growth.

Leaf tissues of the 10- and 12-h photoperiod were significantly thicker than those under the 14-, 16-h, or field conditions (Tables 2 and 3). Plants grown in the field and those under 14or 16-h photoperiods had similar leaf thicknesses (Table 3). There are two palisade mesophyll layers in all the leaf tissues; clearly, the longer palisade mesophyll cells that developed under 10 and $12 \mathrm{~h}$ of light contributed to the increase in leaf thickness (Fig. $3 \mathrm{~A}$ and B vs. C-E; Table 3). Cells of the lower epidermis were smallest under the 10- and 12-h photoperiods, while cells of the upper epidermis were largest under the 10-, 12-h, and field photoperiods. A significant linear relationship existed for leaf thickness and daylength (Table 2).

Thermoperiod (Expt. 2). Daytime temperature had a significant effect on leaf count, area, and weight, and stem weight of Heptacodium, but not on root weight or shoot length (Table 4). During days at $30 \mathrm{C}$, and stem growth was greater than at $22 \mathrm{C}$ (Table 5). Nights at $18 \mathrm{C}$ resulted in larger and heavier leaves and in higher shoot weight than nights at $26 \mathrm{C}$. There were no differences in the root weight, shoot length, and leaf count between the two night temperatures. Day and night temperatures did not show any interaction effects (Table 5). In azaleas, shoot elongation and number of leaves were strongly affected by temperature and daylength (Pettersen, 1972). A higher rate of growth was obtained under long than under short days, with a more pronounced difference at higher temperature. Barrick and Sanderson (1973) also reported temperature-dependent differences in shoot length and shoot count for greenhouse azaleas.

Day temperature did not significantly influence any of the leaf tissues except the upper epidermis. In contrast, night temperature significantly affected the development of the palisade layers, the lower epidermis, and the entire leaf thickness (Table $6)$. The higher significant night temperature effect on total leaf thickness may have resulted from the significant day/night interaction. 
We conclude that photoperiod had a pronounced effect on the vegetative growth of $H$. miconioides. Long days increased growth responses, while short days reduced growth and induced dormancy. High day and low night temperatures enhanced leaf and stem growth.

\section{Literature Cited}

Barrick, W.E. and K.C. Sanderson. 1973. Influence of photoperiod, temperature, and node position on vegetative shoot growth of greenhouse azaleas, Rhododendron cv. J. Amer. Soc. Hort. Sci. 98:331334.

Downs, R.J. and H.A. Borthwick. 1956. Effect of photoperiod upon the vegetative growth of Weigela florida var. Variegata. Proc. Amer. Soc. Hort. Sci. 68:518-521.
Downs, R.J. and J.F. Thomas. 1991. Phytotron procedural manual for controlled environment research at the Southeastern Plant Environment Laboratory. Tech. Bul. 244 (revised). North Carolina Agricultural Research Service, North Carolina State Univ., Raleigh.

Hu, J.Q. 1988. Heptacodium. Flora Reipublicae Popularis Sinicae. vol. 72. Beijing Science Press. p. 108-110.

Johansen, D.A. 1940. Plant microtechnique. McGraw-Hill, New York.

Keller, G. 1986. Seven-son flower from Zhejiang: Introducing the versatile ornamental shrub Heptacodium jasminoides Airy-Shaw. Arnoldia 46:2-14.

Pettersen, H. 1972. The effect of temperature and daylength on shoot growth and bud formation in azalea. J. Amer. Soc. Hort. Sci. 97:1724.

Vince-Prue, D. 1975. Photoperiodism in plants. McGraw-Hill, New York. 